University of Nebraska - Lincoln

DigitalCommons@University of Nebraska - Lincoln

Nebraska Game and Parks Commission -- Staff

Research Publications

Nebraska Game and Parks Commission

April 1961

\title{
Extension of the Range of Northern Pike (Esox lucius)
}

D. B. McCarraher

Nebraska Game, Forestation and Parks Commission, Bassett, Nebraska

Follow this and additional works at: https://digitalcommons.unl.edu/nebgamestaff

Part of the Environmental Sciences Commons

McCarraher, D. B., "Extension of the Range of Northern Pike (Esox lucius)" (1961). Nebraska Game and Parks Commission -- Staff Research Publications. 6.

https://digitalcommons.unl.edu/nebgamestaff/6

This Article is brought to you for free and open access by the Nebraska Game and Parks Commission at DigitalCommons@University of Nebraska - Lincoln. It has been accepted for inclusion in Nebraska Game and Parks Commission -- Staff Research Publications by an authorized administrator of DigitalCommons@University of Nebraska - Lincoln. 
Made in United States of America

Reprinted from Transactions of the American Fisheries Society

Vol. 90, No. 2, April, 1961

pp. $227-228$

\section{Extension of the Range of Northern Pike (Esox lucius) ${ }^{1}$}

Recent technical publications and popular literature have not fully established the present geographical range of the northern pike. A survey by the writer ${ }^{2}$ in 1955 showed that 26 states and Canadian provinces had resident northern pike populations. During the past 5 years pike have been introduced into several other states, thus extending the range. Pike are already established in most of the northern states and are now being released into waters of the south and west.

North Carolina, according to Cornell, ${ }^{3}$ has attempted to introduce this species in waters of the coastal plains, Piedmont, and mountain sections of the state. These plantings to date appear to be unsuccessful. To our knowledge these releases are the most southern introductions attempted. Maryland has achieved some success in its pike introductions, according to Elser. ${ }^{4}$ Adults and eggs have been planted in the 3,900-acre Deep Creek Lake located in

${ }^{1}$ A contribution of Federal Aid to Fisheries, F-4 R, Job No. 6.

2 McCarraher, D. B. (1955) The status of the northern pike, Esox lucius, in North America. Paper presented at the 17th Midwest Wildlife Conference.

${ }^{3}$ Personal communication from J. H. Cornell, Fish Division, North Carolina Wildlife Resources Commission, January 6, 1960.

${ }^{4}$ Personal communication from Harold J. Elser, Maryland Department of Research and Education, December 23, 1959. 
western Maryland. Pike growth and survival has been recorded, but natural reproduction has yet to be established. Fisheries workers throughout the Mid-south are watching closely the pike releases in Deep Creek Lake in order to evaluate angling and predatory value in Mid-southern waters.

The western range of northern pike in the United States is now extended to Colorado and Montana. Montana has achieved some success with pike introductions in large ranch ponds and small reservoirs throughout the eastern third of the state. Colorado has introduced pike in Bonny Reservoir, Yuma County, and in Skaguay Reservoir in Teller County. These impoundments range in elevation from 3,500 feet (Bonny) to over 10,000 feet (Skaguay). Lynch ${ }^{5}$ indicates that future plantings may be restricted to the eastern section of Colorado, especially the plains area.

The distribution of pike throughout the Canadian Arctic appears sporadic. Conclusive evidence is lacking in some arctic watersheds and more investigational work is needed to determine the exact range status. Hunter ${ }^{6}$ presented a synoptic review of pike distribution in the Canadian Arctic. He mentions that the species is found in some of the coastal streams west of the Mackenzie River to the Alaskan border, where range extension in the Beaufort Sea is possible. It is abundant throughout the Mackenzie watershed including Great Bear and Great Slave Lakes. Pike have been reported from all the rivers emptying into the west coast of Hudson's Bay, south of the Maguse River system. Pike have not been collected from any of the arctic islands.

From the increased interest by fisheries workers throughout the country in the northern pike we can expect to see a continued geographical enlargement of the principal range of the species.

D. B. McCarraher

Nebraska Game, Forestation and Parks Commission Bassett, Nebraska

\footnotetext{
${ }^{5}$ Personal communication from Tom M. Lynch, Colorado Game and Fish Department, December 24, 1959.

${ }^{6}$ Personal communication from J. G. Hunter, Arctic Unit, Fisheries Research Board of Canada, March $16,1960$.
} 